\title{
PENGARUH PEMBELAJARAN PROBLEM BASED LEARNING TERHADAP KEMAMPUAN KOMUNIKASI DAN SELF EFFICACY MATEMATIS SISWA
}

\section{THE EFFECT OF PROBLEM BASED LEARNING ON COMMUNICATION SKILLS AND STUDENTS 'MATHEMATIC SELF EFFICACY}

\author{
ERNAWATI \\ Guru SMK Alwashliyah, \\ Jl. Suka Mulia Aek Kanopan : email: erwatierna8@gmail.com
}

\begin{abstract}
Abstrak
Tujuan penelitian ini adalah untuk mengetahui 1) apakah ada pengaruh pembelajaran problem based learning terhadap kemampuan komunikasi matematis siswa di kelas X SMK, dan 2) apakah ada pengaruh kepercayaan diri siswa setelah mengikuti pembelajaran problem based learning. Jenis penelitian adalah kuantitatif. Populasi penelitian seluruh kelas $\mathrm{X}$ berjumlah 89 orang dan sampel kelas X Akuntasi sebanyak 33 orang. Teknik pengumpulan data dengan tes dan nontes, dengan teknik analisis data yang digunakan adalah uji normalitas, uji homogenitas, uji hipotesis atau uji t. Berdasarkan hasil tes yang diberikan rata-rata nilai pretest siswa adalah 18.85 dan standar deviasi 4.512 dan rata-rata nilai posttest siswa adalah 27.57 dan standar deviasi 5.321, hal ini menunjukkan bahwa kemampuan komunikasi siswa berpengaruh setelah diberikan perlakuan (pembelajaran problem based learning). Hasil nontes yang diberikan rata-rata nilai awal siswa adalah 27.45 dengan standar deviasi 6.860 dan rata-rata nilai akhir 46.39 dan standar deviasi 7.318 hal ini menunjukkan bahwa kemampuan self efficacay siswa berpengaruh setelah diberikan perlakuan (pembelajaran problem based learning). Berdasarkan pengujian hipotesis pertama menggunakan uji t dengan teknik indenfendent samples t-test ditunjukkan bahwa kelas eksperimen pada taraf signifikan $\alpha=0.05$, dengan nilai sig $0.000>0.005$, maka $\mathrm{H} 0$ ditolak Ha diterima berarti ada pengaruh pembelajaran problem based learning terhadap kemampuan komunikasi matematika siswa. Hipotesis kedua menggunakan uji t dengan teknik indenfendent samples t-test ditunjukkan bahwa kelas eksperimen pada taraf signifikan $\alpha=0.05$ dengan nilai sig $0.000>0.005$ maka $\mathrm{HO}$ ditolak Ha diterima berarti ada pengaruh pembelajaran problem based learning terhadap kemampuan self efficacy matematika siswa.
\end{abstract}

\section{Kata kunci : Pembelajaran Problem Based Learning, Kemampuan Komunikasi, Self Efficacy}

\begin{abstract}
The purpose of this study was to determine 1) whether there is an effect of problem based learning on students' mathematical communication skills in class X SMK, and 2) whether there is an effect of student self-confidence after participating in problem based learning. This type of research is quantitative. The research population of all class $\mathrm{X}$ amounted to 89 people and the sample class $\mathrm{X}$ accounting as many as 33 people. Data collection techniques with test and non-test, with data analysis techniques used are normality test, homogeneity test, hypothesis test or $t$ test. Based on the test results given the average pretest score of the students was 18.85 and the standard deviation was 4.512 and the average posttest score of the students was 27.57 and the standard deviation was 5.321, this shows that the students' communication skills had an effect after being given treatment (problem based learning). The results of the non-test given that the average initial score of students were 27.45 with a standard deviation of 6,860 and an average final score of 46.39 and a standard deviation of 7,318 , this shows that the students' self-efficacy ability has an effect after being given treatment (problem based learning). Based on testing the first hypothesis using the $t$ test with indentent samples t-test technique, it is shown that the experimental class is at a significant level of $\alpha=0.05$, with a sig value of $0.000>0.005$, then $\mathrm{HO}$ is rejected. $\mathrm{Ha}$ is accepted, meaning that there is an effect of problem based learning on students' mathematical communication skills. The second hypothesis using the $t$ test with indentent samples $t$-test technique shows that the experimental class is at a significant level of $\alpha=0.05$ with a sig value of $0.000>$ 0.005 , then $\mathrm{HO}$ is rejected. $\mathrm{Ha}$ is accepted, which means that there is an effect of problem based learning on students' mathematical self-efficacy.
\end{abstract}

Key Words : Learning Problem Based Learning, Communication Skills, Self Efficacy 
Hal : $62-71$

\section{Pendahuluan}

Belajar matematika adalah aktivitas yang disengaja untuk mendapatkan suatu pengetahuan baik secara langung maupun tidak langsung melalui lingkungan yang dapat mengakibatkan perubahan tingkah laku pada seseorang [3]. Tujuan pembelajaran matematika pada setiap jenjang pendidikan yang telah diaturdalam kurikulum.Keberhasilan suatu pengajaran bisa dikatakan efektif apabila terdapat kemampuan dalam melakukan pengajaran sebagai usaha untuk keseimbangan antara kualitas dan kuantitas pengajaran. Matematika merupakan ilmu yang sangat penting dalam kehidupan sehari - hari dan dalam lingkungan sekolah, oleh karena itu siswa dituntut untuk menguasai matematika, agar siswa dapat memahami matematika secara menyeluruh serta merasakan kebermanfaatannya, maka siswa diharuskan untuk menguasai beberapa kemampuan matematika salah satunya yaitu kemampuan komunikasi matematis.

Kemampuan Komunikasi merupakan bagian yang sangat penting pada pembelajaran matematika. Komunikasi merupakan cara berbagi ide dan memperjelas pemahaman [8]. Melalui komunikasi ide dapat dicerminkan, diperbaiki, didiskusikan, dan dikembangkan. Proses komunikasi juga membantu membangun makna, mempermanenkan ide, dan juga dapat mempublikasikan ide. Ketika para siswa ditantang berpikir dan kemampuan berpikir mereka tentang matematika serta mengkomunikasikan hasil pemikiran mereka secara lisan atau dalam bentuk tulisan, maka mereka sedang belajar menjelaskan dan menyakinkan mengenai konsep matematika.

Pentingnya komunikasi diungkapkan juga oleh [2] menyatakan Komunikasi merupakan kemampuan yang sangat penting dimiliki siswa dalam mempelajari matematika, baik siswa sekolah dasar maupun menengah dituntut untuk memiliki kemampuan komunikasi yang baik. Kemampuan komunikasi serta kemampuan kepercayaan diri (self efficacy) dapat, menyampaikan informasi atau mengkomunikasikan gagasan. Self efficacy juga merupakan bagian penting dalam belajar matematika. Sebab self efficacy (kemampuan diri) matematis adalah salah satu ranah afektif yang memengaruhi kemampuan komunikasi matematis. Menurut [5] self efficacy menentukan pilihan tindakan kita, upaya yang kita keluarkan, kegigihan kita dalam menghadapi kesulitan, dan pengalaman emosional atau afektif kita [4]. Maka dapat disimpulkan bahwa Self-efficacy matematis adalah pandangan seseorang terhadap kemampuan dirinya/kepercayaan dirinya dalam mengatur dan menentukan suatu pekerjaan. Dari pemaparan diatas dapat ditarik kesimpulan bahwa kemampuan komunikasi dan self-efficacy adalah dua hal yang sangat penting dimiliki oleh siswa dan saling berkaitan satu sama lain [10]. Seorang siswa yang yakin akan kemampuan dirinya diharapkan kemampuan berkomunikasinya pun akan baik, begitupun sebaliknya. keuntungan jika siswa memiliki komunikasi dan self efficacy yang baik yaitu siswa lebih mudah menyelesaiakan masalah yang di berikan guru dan memiliki kepercayaan diri untuk menyelesaiakan tugas. Dapat diketahui bahwa siswa SMK khususnya siswa kelas $X$ yang masih dalam proses masa peralihan dari Sekolah menengah pertama ke Sekolah Menengah atas oleh sebab itu mereka masih belum menguasai kemampuan komunikasi dan kepercaya diri(self efficacy).

Berdasarkan hasil observasi disekolah SMK Swasta Az-Zahra Sonomartani seorang guru menyatakan bahwa pembelajaran matematika di SMK Swasta Az-Zahra Sonomartani masih menggunakan pendekatan konvensional. Yang mengakibatkan rendahnya kemampuan komunikasi matematis siswa, karena saat mengajar guru masih menjadi pusat pembelajaran, sedangkan siswa cenderung pasif menerima materi yang guru sampaikan. Selama ini guru melakukan kegiantan proses belajar secara monoton dan serius sehingga siswa takut untuk menanyak pembelajaran yang mereka tidak tahu, yang menyebabkan kemampuan komunikasi siswa dan kepercayaan diri siswa kurang.

Masih banyak siswa yang mengalami kesulitan belajar matematika dan siswa lemah dalam kemampuan komunikasi matematisnya. Salah satu bukti rendahnya kemampuan komunikasi dan self efficacy matematis siswa yakni ketidakmampuan siswa dalam menyebutkan simbol - simbol matematika dan menjawab soal ulangan harian yang menuntut kemampuan komunikasi matematis siswa. Dan siswa masih merasa takut untuk menuliskan dan menjelaskan hasil pekerjaan rumahnya di depan kelas yang diminta guru. Siswa takut salah karena tidak yakin dengan jawaban yang mereka peroleh dan juga tidak yakin mereka mampu menjelaskan dengan baik. Telah terbukti saat dilakukannya observasi di SMK Swasta Az-Zahra Sonomartani sebagaimana masih terlihat rendahnya kemampuan komunikasi dan self eficacy matematika pada peserta didik pada saat pemberian tes dan nontes. Dengan soal tentukanlah suku ke-10 dari barisan $5,10,15,20 \ldots$ ? dari observasi pada penelitian ini terlihat bahwa peserta didik tidak bisa menyelesaikan soal dengan baik. 
Hal : $62-71$

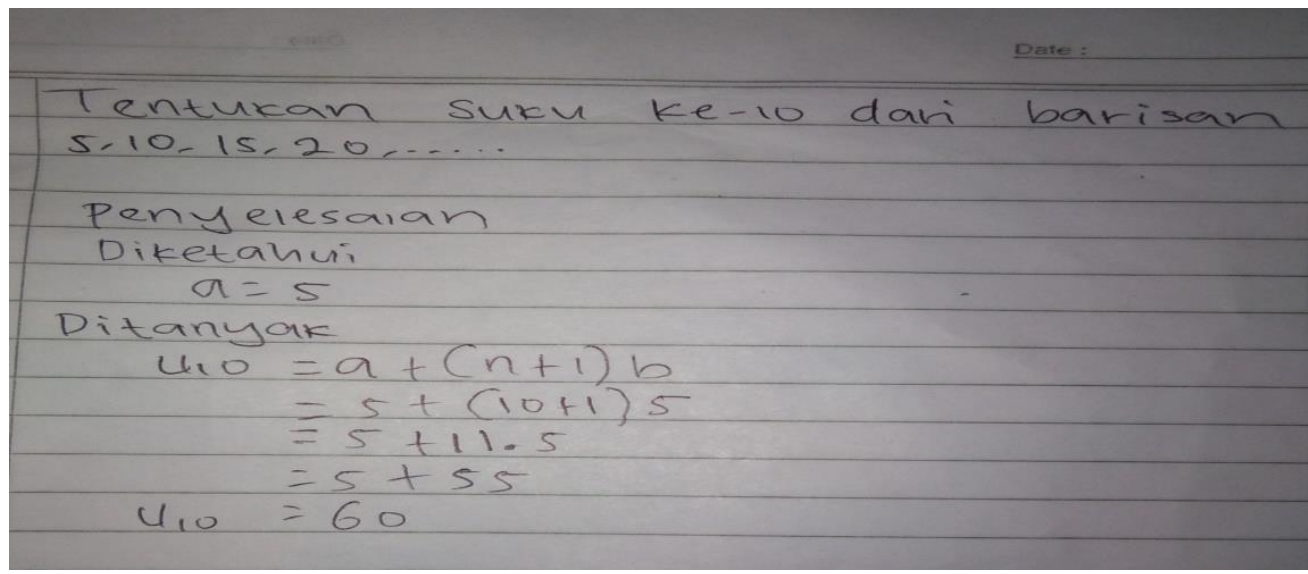

Gambar 1. Tes Kemampuan Komunikasi

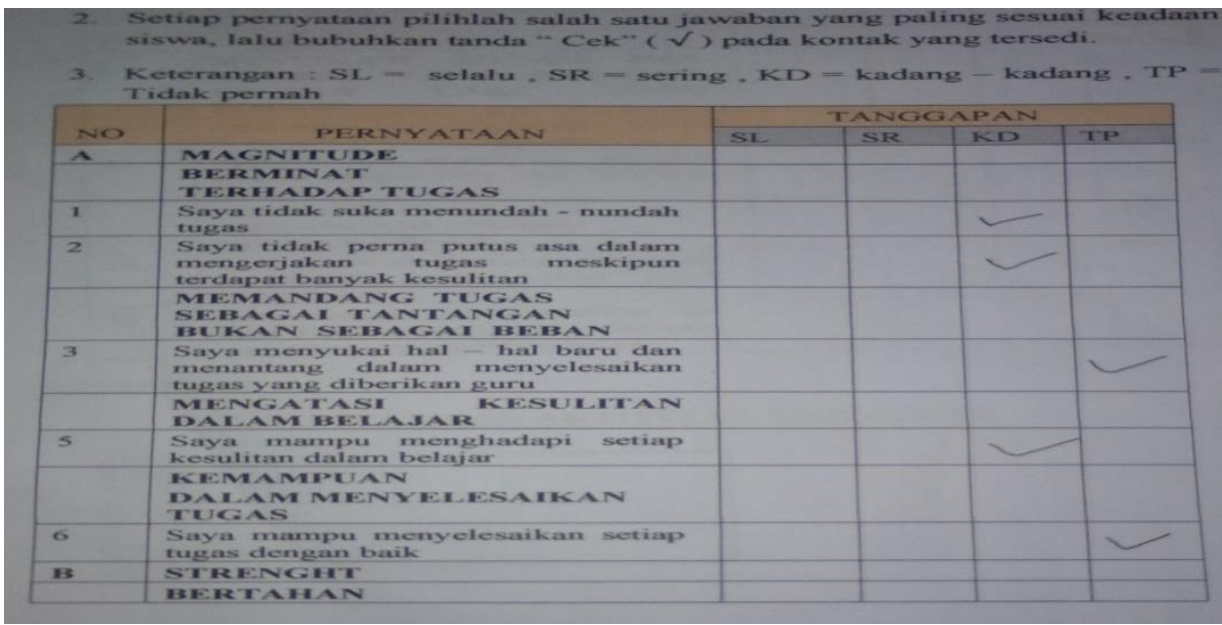

Gambar 2. Tes Angket Self Efficacy

Penyelesaian tersebut menunjukan bahwa siswa kurang mampu memahami simbol matematika dan sering salah dalam menggunakanya, sehingga siswa mengalami kesulitan dan sering terjadi kekeliruan dalam menafsirkan soal ke dalam simbol maupun model matematika pada saat mengerjakan soal- soal komunikasi.Dan penyelesaian tes angket menujunkan siswa masih kurang dalam kepercayaan diri dan rata rata siswa menjawab tidak pernah.

Pemilihan strategi pengajaran dalam proses belajar mengajar matematika merupakan hal yang penting di pertimbangkan guru untuk meningkatkan kemampuan komunikasi dan self efficacy siswa. Seorang guru matematika harus mencari dan menemukan teknik - teknik yang lebih efektif dan bervariasi untuk membuat belajar lebih menarik bagi siswa. strategi yang cocok untuk menguasi kemampuan komunikasi siswa dan self efficacy siswa ialah pembelajaran Problem based learning [9].

Melalui pembelajaran Problem Based Learning (PBL) siswa dilatih untuk memecahkan masalah yang ada dan bekerja dalam kelompok sehingga siswa lebih aktif dalam mengontruksi pembelajarannya [6]. Pembelajaran model Problem Based Learning (PBL) memiliki beberapa keunggulan, diantaranya dapat meningkatkan hasil belajar peserta didik dan memudahkan peserta didik untuk memahami isi pelajaran. Dan model problem based learning telah meningkatkan aktivitas siswa, selain meningkatkan aktivitas belajar siswa yang menjadi keunggulan dari problem based learning adalah membantu siswa dalam meningkatkan interaksi antar siswa dan rasa percaya diri siswa di dalam suatu masalah [7]. Dengan pembelajaran ini siswa dapat berkomunikasi di dalam kelompok untuk untuk memecahkan masalah dan siswa lebih percaya diri untuk memberi pendapat. 
Hal : $62-71$

\section{Metode Penelitian}

Jenis penelitian adalah jenis penelitian kuantitatif, Desain yang digunakan dalam penelitian ini adalah One-Group-pretest-posttest. Dalam kegiatan uji coba tidak menggunakan kelas kontrol. Design ini dilakukan dengan membandingkan hasil pretest dan posttest [1] pada kelompok yang diujicobakan, Penelitian ini dilaksanakan di SMK Swasta Az-Zahra Sonomartani Waktu penelitian dilaksanakan pada semester genap tahun pelajaran 2019/2020. populasi dalam penelitian ini adalah seluruh siswa kelas XSMK Swasta Az-Zahra Sonomartani, sampel dalam penelitian ini kelas X Akuntansi dengan jumlah siswa 33 siswa. Adapun metode pengumpulan data dalam penelitian ini adalah melalui tes uraian dan nontes yang disesuaikan dengan kurikulum yang berlaku, Adapun tes yang gunakan untuk penelitian ini berbentuk tes uraian yang berjumlah 5 soal dan nontes berupa angket.

\section{Hasil Penelitian dan Pembahasan}

\section{Hasil penelitian}

Pengujian tes kemampuan komunikasi dan nontes kemampuan self efficacy matematika siswa dalam penelitian ini dilakukan di kelas X Smk Az-Zahra Sonomartani Tahun ajaran 2019/2020.Dalam penelitian ini, peneliti menggunakan satu kelas sebagai kelas sampel, yaitu kelas X-Akuntansi sebagai kelas eksperimen dengan jumlah siswa 33 siswa. Untuk mengetahui kemampuan komunikasi dan self efficacy matematika siswa, data yang telah dihitung akan dianalisis secara deskriptif. Secara ringkas hasil penelitian dapat dideskripsikan seperti terlihat pada tabel di bawah ini :

Tabel 1. Perbedaan Hasil Belajar pre test dan post test

\begin{tabular}{|l|l|l|}
\hline \multicolumn{1}{|c|}{ Sumber Statistik } & \multicolumn{1}{c|}{ Pre Test } & \multicolumn{1}{c|}{ Post test } \\
\hline \multirow{4}{*}{$\begin{array}{l}\text { Pembelajaran Problem Based } \\
\text { Learning }\end{array}$} & $\mathrm{n}=33$ & $\mathrm{n}=33$ \\
\cline { 2 - 3 } & $\sum \mathrm{X}=1885$ & $\sum \mathrm{X}=2757$ \\
\cline { 2 - 3 } & $\sum \mathrm{X}^{2}=107800$ & $\sum \mathrm{X}^{2}=231169$ \\
\cline { 2 - 3 } & $\mathrm{SD}=4.512$ & $\mathrm{SD}=5.321$ \\
\cline { 2 - 3 } & Var $=209.3851$ & Var $=226.4885$ \\
\cline { 2 - 3 } & Mean $=5712$ & Mean $=8355$ \\
\hline
\end{tabular}

Deskripsi masing-masing tes dapat diuraikan berdasarkan hasil analisis tendensi sentral seperti terlihat pada rangkuman hasil sebagai berikut:

1) Data pre test Kemampuan komunikasi Matematika Siswa yang Dilakukan sebelum Pembelajaran Problem Based Learning.

Berdasarkan data yang diperoleh dari hasil pre-test untuk mengukur kemampuan komunikasi matematis siswa yang belum dilakukan dengan pembelajaran Problem Based Learning (PBL), diperoleh data distribusi frekuensi pada lampiran 20. Dari perhitungan tersebut diperoleh nilai rata-rata hitung (mean) sebesar 57,12, dan standar deviasi (SD) = 4.512.

Dari data tersebut dapat diketahui bahwa kemampuan komunikasi matematis siswa yang dilakukan sebelum pembelajaran Problem Based Leraning (PBL). Diperoleh data distribusi frekuensi pada lampiran 20.memperoleh nilai rata-rata (mean) siswa sebesar 57,12dan standar deviasi (SD) sebesar 4.512 serta memiliki nilai yang sangat beragam atau berbeda antara siswa yang satu dengan siswa yang lainnya, karena dapat kita lihat bahwa nilai varians semua dalam kategori sedang. Untuk mengitung data distribusi frekuensi dapat dilihat pada lampiran 21 dan Secara kuantitatif dapat dilihat pada tabel berikut ini :

Tabel 2. Distribusi Frekuensi

\begin{tabular}{|c|c|c|c|}
\hline Kelas & Interval Kelas & $\mathbf{F}$ & $\mathbf{F r}$ \\
\hline 1 & $30,5-37,5$ & 0 & $0 \%$ \\
\hline 2 & $37,5-44,5$ & 0 & $0 \%$ \\
\hline 3 & $44,5-51,5$ & 5 & $16 \%$ \\
\hline 4 & $51,5-58,5$ & 13 & $39 \%$ \\
\hline 5 & $58,5-65,5$ & 15 & $45 \%$ \\
\hline 6 & $65,5-72,5$ & 0 & $0 \%$ \\
\hline 7 & $72,5-77,5$ & 0 & $0 \%$ \\
\hline \multicolumn{2}{|c|}{ Jumlah } & 33 & $100 \%$ \\
\hline
\end{tabular}


Hal : $62-71$

Berdasarkan nilai-nilai tersebut, dapat dibentuk diagram batang data kelompok sebagai berikut:

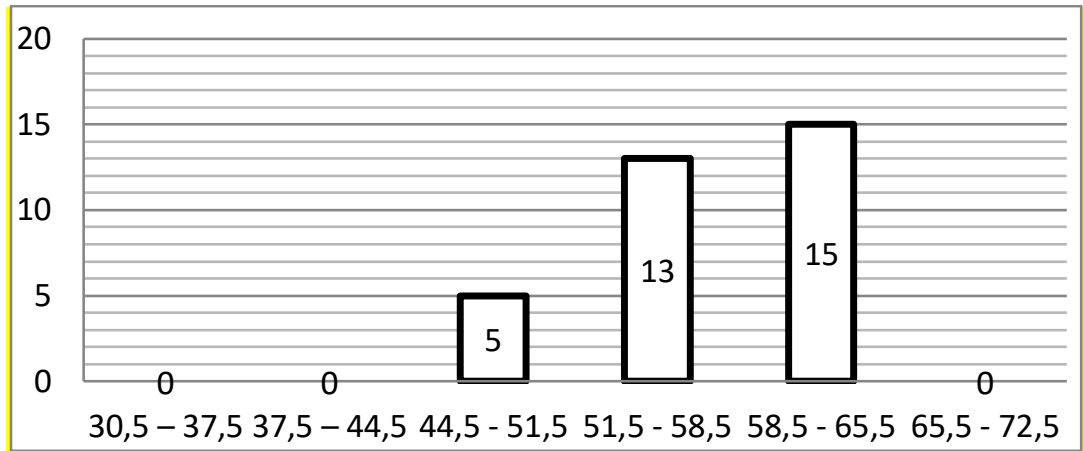

Gambar 3. Diagram pre test kemampuan komunikasi

Tabel 3. Kategori Penilaian

\begin{tabular}{|c|c|c|c|c|}
\hline No & Ketentuan & Jumlah Siswa & Presentase & $\begin{array}{c}\text { Kategori } \\
\text { Penilaian }\end{array}$ \\
\hline 1 & $>76.63$ & 0 & $0 \%$ & Tinggi \\
\hline 2 & 47.69 s.d 76.63 & 33 & $100 \%$ & Sedang \\
\hline 3 & $<47.69$ & 0 & $0 \%$ & Rendah \\
\hline
\end{tabular}

Dari tabel di atas dapat diketahui bahwa kemampuan komunikasi matematis siswa yang dilakukan sebelum pembelajaran Problem Based Leraning (PBL) diperoleh: Jumlah siswa yang memiliki nilai kategori sedang sebanyak 33 orang atau sebesar 100\%, hal ini berarti siswa belum sepenuhnya dalam berkemampuan komunikasi. Siswa masih mampu mengidentifikasi salah satu dari yang diketahui atau ditanyakan, kemudian dalam menguraikan langkah-langkah penyelesaian atau rumus, siswa dapat menuliskannya tetapi masih terdapat beberapa kesalahan dan hanya berfokus pada jawaban akhir yang mereka anggap benar serta mereka menuliskan penjelasan dengan benar, namun masih terdapat keterangan-keterangan atau kesimpulan akhir yang tidak sesuai. Secara keseluruhan diperoleh nilai ratarata $($ Mean $)=57,12$ maka dapat disimpulkan kemampuan komunikasi matematis siswa yang dilakukan sebelum pembelajaran Problem Based Leraning (PBL) dapat dikategorikan sedang, yakni secara umum siswa masih mampu memahami masalah secara sebagian, artinya siswa dapat menuliskan apa yang diketahui atau yang ditanyakan secara benar, dan siswa hanya menuliskan jawaban akhir saja dan tidak menguraikan langkah penyelesaian serta penjelasan dengan lengkap atau tepat karena masih terdapat beberapa kesalahan dalam penjelasan atau perhitungan.

\section{2) Data Post test Kemampuan komunikasi Matematika Siswa yang Dilakukan Setelah Pembelajaran Problem Based Learning.}

Berdasarkan data yang diperoleh dari hasil post-test untuk mengukur kemampuan komuikasi matematis siswa yang dilakukan setelah pembelajaran Problem Based Learning(PBL), diperoleh data distribusi frekuensi pada lampiran 20. Dari perhitungan tersebut diperoleh nilai rata-rata hitung (mean) sebesar $=83,55$, dan standar deviasi $(S D)=5.321$. Dari data tersebut dapat diketahui bahwa kemampuan Komunikasi matematis yang dilakukan setelah pembelajaran Problem Based Learning(PBL), memperoleh nilai rata-rata (mean) siswa sebesar 83,55dan standar deviasi (SD) sebesar 5.321serta memiliki nilai yang sangat beragam atau berbeda antara siswa yang satu dengan siswa yang lainnya, karena dapat kita lihat bahwa nilai tertinggi yakni 95. Yang diperoleh data distribusi frekuensi pada lampiran 21 dan Secara kuantitatif dapat dilihat pada tabel berikut ini :

Tabel 4. Distribusi Frekuensi

\begin{tabular}{|c|c|c|c|}
\hline Kelas & Interval Kelas & F & Fr \\
\hline 1 & $51,5-58,5$ & 0 & $0 \%$ \\
\hline 2 & $58,5-65,5$ & 0 & $0 \%$ \\
\hline 3 & $65,5-72,5$ & 0 & $0 \%$ \\
\hline 4 & $72,5-79,5$ & 7 & $21 \%$ \\
\hline 6 & $79,5-86,5$ & 19 & $58 \%$ \\
\hline 7 & $86,5-93,5$ & 5 & $15 \%$ \\
\hline & $93,5-100$ & 2 & $6 \%$ \\
\hline
\end{tabular}


$\mathrm{Hal}: 62-71$

Berdasarkan nilai-nilai tersebut, dapat dibentuk diagram batang data kelompok sebagai berikut:

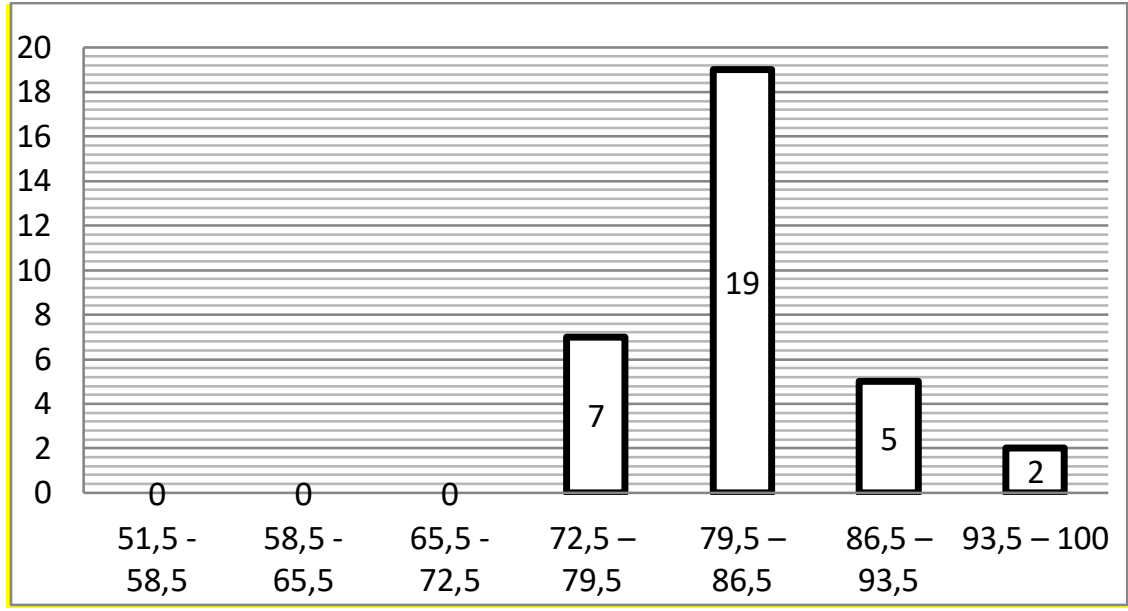

Gambar 4. Diagram post test kemampuan komunikasi

Tabel 5. Kategori Penilaian

\begin{tabular}{|c|c|c|c|c|}
\hline No & Ketentuan & $\begin{array}{c}\text { Jumlah } \\
\text { Siswa }\end{array}$ & Presentase & $\begin{array}{c}\text { Kategori } \\
\text { Penilaian }\end{array}$ \\
\hline 1 & $>80.99$ & 26 & $78 \%$ & Tinggi \\
\hline 2 & 54.68 s.d 80.99 & 7 & $21 \%$ & Sedang \\
\hline 3 & $<54.68$ & 0 & $0 \%$ & Rendah \\
\hline
\end{tabular}

Dari tabel di atas dapat diketahui bahwa kemampuan komunikasi matematis yang dilakukan setelah pembelajaran Problem Based Learning(PBL), diperoleh: (1) Jumlah siswa yang memiliki nilai kategori tinggi sebanyak 26 orang atau sebesar $78 \%$. Dari hasil tersebut berarti siswa dapat memahami masalah pada tes kemampuan komunikasi yang dimana siswa mampu menyelesaikan soal dengan baik, yaitu siswa menuliskan apa diketahui dan ditanya dengan benar, kemudian siswa juga dapat menuliskan langkah penyelesaian atau rumus dan jawaban dengan benar. (2) Jumlah siswa yang memiliki nilai kategori sedang sebanyak 7 orang atau sebesar $21 \%$, hal ini berarti siswa belum sepenuhnya dalam memahami masalah. Siswa masih belum mampu mengidentifikasi salah satu dari yang diketahui atau ditanyakan, kemudian dalam menguraikan langkah-langkah penyelesaian atau rumus, siswa dapat menuliskannya tetapi masih terdapat beberapa kesalahan dan hanya berfokus pada jawaban akhir yang mereka anggap benar.

\section{3) Data Pre-test Kemampuan Self Efficacy (kepercayaan diri) yang Dilakukan sebelum Pembelajaran Problem Based Learning.}

Data Self Efficacy ( kepercayaan diri) pre test (Y1) diperoleh dari angket yang terdiri dari 15 item dengan 4 alternatif jawaban, dimana 4 untuk skor tertinggi dan 1 untuk skor terendah. Deskripsi data self efficacy dapat dilihat pada Tabel 6.

Tabel 6. Deskripsi Data Self Efficacy pada Pre-test ( Y1)

\begin{tabular}{|l|l|l|l|l|l|l|}
\hline \multicolumn{1}{|c|}{ Data } & Mean & Median & Modus & $\begin{array}{c}\text { Std. } \\
\text { Deviasi }\end{array}$ & $\begin{array}{c}\text { Skor } \\
\text { Maxi }\end{array}$ & $\begin{array}{c}\text { Skor } \\
\text { Min }\end{array}$ \\
\hline X1 & 2745 & 27 & 27 & 6.860 & 45 & 17 \\
\hline \multicolumn{5}{|l|}{} \\
\hline Skor Max. Ideal & $=15$ \\
\hline Skor Min. Ideal & $=60$ \\
\hline Mean Ideal & $=37,5$ \\
\hline Std. Deviasi Ideal & $=22,5$ \\
\hline
\end{tabular}

Selanjutnya data disajikan dalam tabel distribusi frekuensi,yang diperoleh data distribusi frekuensi. Dan hasil dapat dilihat pada Tabel 7. 
Hal : $62-71$

Tabel 7. Distribusi Frekuensi Self Efficacy

\begin{tabular}{|c|c|c|c|}
\hline Kelas & Interval Kelas & F & Fr \\
\hline 1 & $15-20$ & 7 & $21 \%$ \\
\hline 2 & $21-32$ & 6 & $19 \%$ \\
\hline 3 & $27-32$ & 11 & $33 \%$ \\
\hline 4 & $33-38$ & 7 & $21 \%$ \\
\hline 5 & $39-44$ & 1 & $3 \%$ \\
\hline 6 & $45-50$ & 1 & $3 \%$ \\
\hline
\end{tabular}

Berdasarkan Tabel , dapat dibuat diagram kolom (column chart) pada Gambar 4.3.

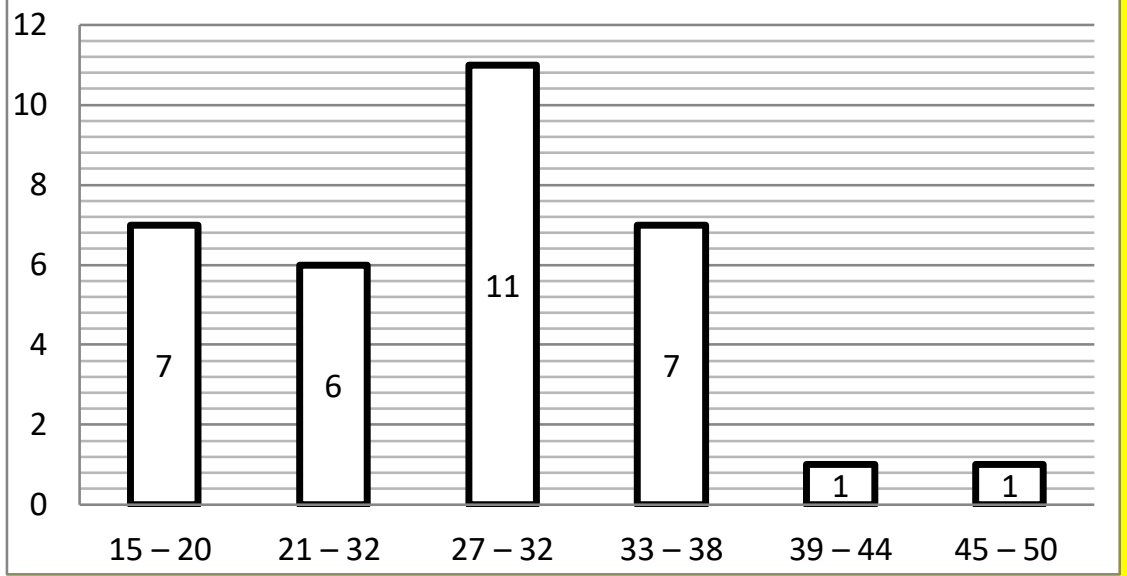

Gambar 5. Diagram pre test kemampuan Self Efficacy

Selanjutnya data disajikan dalam tabel kategorisasi skor Self Efficacy pada Tabel 8.

Tabel 8. Kategorisasi Skor Pre-test Self Efficacy

\begin{tabular}{|c|c|c|c|}
\hline Skor & Frekuensi & Frekuenai relatif $\%$ & Kategori \\
\hline$\leq 20$ & 7 & $21 \%$ & Sangat rendah (SR) \\
\hline $21-30$ & 16 & $48 \%$ & Rendah ( R ) \\
\hline $31-40$ & 9 & $28 \%$ & Cukup Tinggi ( CT ) \\
\hline $41-50$ & 1 & $3 \%$ & Tinggi ( T ) \\
\hline Total & 33 & 100 & \\
\hline
\end{tabular}

Berdasarkan kategorisasi skor pre-test Self Efficacy, dapat diketahui bahwa responden dengan Self Efficacy kategori Rendah merupakan responden dengan prosentase terbesar, yaitu $48 \%$.

\section{4) Data Post-test Kemampuan Self Efficacy (kepercayaan diri) yang Dilakukan sesudah Pembelajaran Problem Based Learning.}

Data Self Efficacy ( kepercayaan diri) post test (Y2) diperoleh dari angket yang terdiri dari 15 item dengan 4 alternatif jawaban, dimana 4 untuk skor tertinggi dan 1 untuk skor terendah. Deskripsi data self efficacy dapat dilihat pada Tabel 9.

Tabel 9. Deskripsi Data Self Efficacy pada Post-test (Y2)

\begin{tabular}{|l|c|c|c|c|c|c|}
\hline \multicolumn{1}{|c|}{ Data } & Mean & Median & Modus & $\begin{array}{c}\text { Std. } \\
\text { Deviasi }\end{array}$ & $\begin{array}{c}\text { Skor } \\
\text { Maxi }\end{array}$ & $\begin{array}{c}\text { Skor } \\
\text { Min }\end{array}$ \\
\hline X2 & 46,39 & 46 & 50 & 7.318 & 58 & 26 \\
\hline \multicolumn{7}{|l|}{} \\
\hline Skor Max. Ideal & $=15$ \\
\hline Skor Min. Ideal & $=60$ \\
\hline Mean Ideal & $=37,5$ \\
\hline Std. Deviasi Ideal & $=22,5$ \\
\hline
\end{tabular}


Hal : $62-71$

Selanjutnya data disajikan dalam tabel distribusi frekuensi,yang diperoleh data distribusi frekuensi. Dan hasil dapat dilihat pada Tabel10.

Tabel . 10. Distribusi Frekuensi Self Efficacy (Y2)

\begin{tabular}{|c|c|c|c|}
\hline Kelas & Interval Kelas & $\mathbf{F}$ & Fr \\
\hline 1 & $25-30$ & 1 & $3 \%$ \\
\hline 2 & $31-36$ & 2 & $6 \%$ \\
\hline 3 & $37-42$ & 7 & $21 \%$ \\
\hline 4 & $43-48$ & 9 & $27 \%$ \\
\hline 5 & $49-54$ & 10 & $31 \%$ \\
\hline 6 & $55-60$ & 4 & $12 \%$ \\
\hline \multicolumn{2}{|r}{ Jumlah } & 33 & $100 \%$ \\
\hline
\end{tabular}

Berdasarkan Tabel, dapat dibuat diagram kolom (column chart) pada Gambar 6.

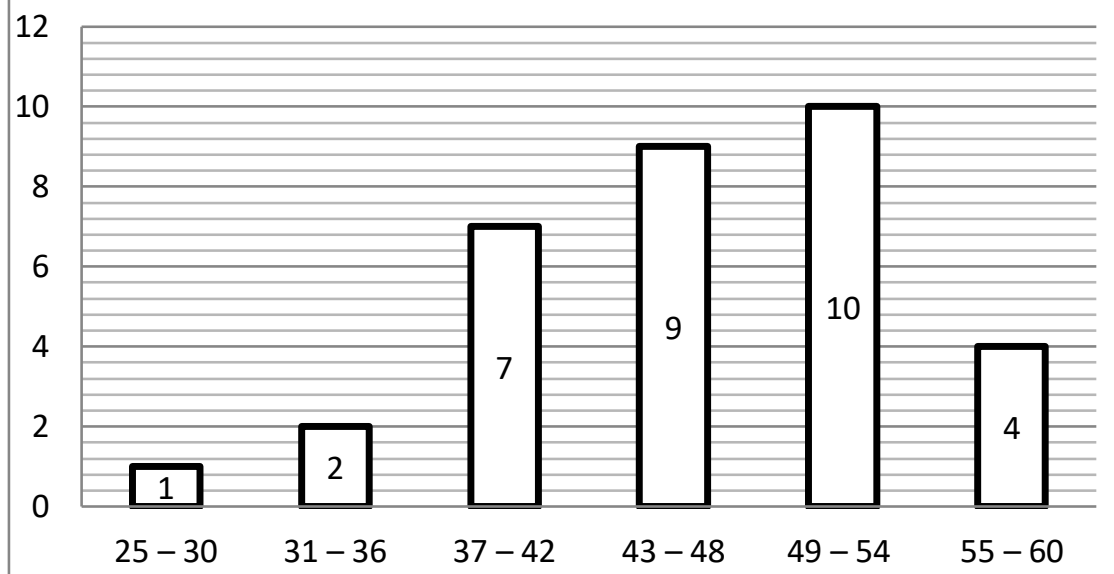

Gambar 6. Diagram post test kemampuan Self Efficacy

Selanjutnya data disajikan dalam tabel kategorisasi skor Self Efficacy pada Tabel 11.

Tabel 11. Kategorisasi Skor Post-test Self Efficacy

\begin{tabular}{|c|c|c|c|}
\hline Skor & Frekuensi & $\begin{array}{c}\text { Frekuenai } \\
\text { relatif } \%\end{array}$ & Kategori \\
\hline$\leq 20$ & 0 & $0 \%$ & Sangat rendah (SR) \\
\hline $21-30$ & 1 & $3 \%$ & Rendah ( R ) \\
\hline $31-40$ & 7 & $21 \%$ & Cukup Tinggi ( CT ) \\
\hline $41-50$ & 16 & $49 \%$ & Tinggi ( T ) \\
\hline $51-60$ & 9 & 100 & \\
\hline Total & 33 & $27 \%$ & Sangat Tinggi (TS ) \\
\hline
\end{tabular}

Berdasarkan kategorisasi skor pre-test Self Efficacy, dapat diketahui bahwa responden dengan Self Efficacy kategori Tinggi merupakan responden dengan prosentase terbesar, yaitu $49 \%$.

\section{Pembahasan}

Penelitian ini dilakukan di SMK Swasta Az - Zahra Sonomartani Jln.Kihajar Dewantara, yang melibatkan satu kelas yaitu kelas eksperimen dimana kelas X Akuntasi yang berjumlah 33 siswa. Pembelajaran yang diberikan pada kelas eksperimen menggunakan pembelajaran Problem Based Learning.Pada bagian ini diuraikan deskripsi dan interpretasi data hasil penelitian. Deskripsi dan interpretasi dilakukan terhadap kemampuan komunikasi matematis siswa yang dilakukan sebelum (pre-test) dan sesudah (post-test) 
Hal : $62-71$

pembelajaran Problem Based Learning . Sesuai dengan data yang diperoleh kemampuan komunikasi akhir matematis siswa kelas eksperimen lebih bagus dari pada kemampuan komunikasi awal, dilihat dari hasil pre test dan post test dikarenakan saat dilakukan pre test siswa belum dapat perlakuan pembelajaran Problem Based Learning sedangkan saat post test sudah dilakukan pembelajaran Problem Based Learning, pada saat pembelajaran siswa menjadi lebih aktif setelah membentuk kelompok, siswa lebih mengerti dan memahami masalah yang diberi dengan berdiskusi bersama teman-teman. Sehingga mereka lebih mudah mengerti saat dilakukan post test.

Dengan penjelasan diatas dapat disimpulkan bahwa antara hasil pre-test dan post-test kemampuan komunikasi matematis siswa kelas eksperimen sebelum dan sesudah pembelajaran problem based learning jauh berbeda. Dengan demikian dapat disimpulkan bahwa pembelajaran Problem Based Learning berpengaruh terhadap kemampuan komunikasi matematis siswa. Deskripsi dan interpretasi dilakukan terhadap kemampuan self efficacy matematis siswa yang dilakukan sebelum (pre-test) dan sesudah (posttest) pembelajaran Problem Based Learning. Sesuai dengan data yang diperoleh kemampuan self efficacy akhir matematis siswa kelas eksperimen lebih bagus dari kemampuanself efficacy awal, dilihat dari hasil pre test dan post test dikarenakan saat dilakukan pre test siswa belum dapat perlakuan pembelajaran Problem Based Learning sedangkan saat post test sudah dilakukan pembelajaran Problem Based Learning, sehingga kepercayaan siswa lebih bagus, siswa memandang tugas yang diberikan guru bukan sebagai beban tapi sebagai tantangan. Siswa lebih semangat/percaya diri dalam mengerjakan tugas yang mereka kerjakan dan hasil akhirnya lebih memuaskan.

Dengan penjelasan diatas dapat disimpulkan bahwa antara hasil pre-test dan post-test kemampuanself efficacy matematis siswa kelas eksperimen sebelum dan sesudah pembelajaran problem based learning jauh berbeda. Dengan demikian dapat disimpulkan bahwa pembelajaran Problem Based Learning berpengaruh terhadap kemampuan self efficacy matematis siswa.

\section{Kesimpulan}

Berdasarkan hasil uji hipotesis yang dilakukan, maka disimpulkan bahwa:

1) Terdapat pengaruh pembelajaran Problem Based Learning terhadap kemampuan komunikasi matematis siswa pada materi Barisan Dan Deret di kelas X Akuntansi SMK Swasta Az - Zahra Sonomartani tahun pelajaran 2019/2020.

2) Terdapat pengaruh pembelajaran Problem Based Learning terhadap kemampuan Self Efficacy matematis siswa pada materi Barisan Dan Deret di kelas X Akuntansi SMK Swasta Az - Zahra Sonomartani tahun pelajaran 2019/2020.

3) Terdapat perbedaan hasil pre-test dan post-test siswa sebelum dan sesudah pembelajaran Problem Based Learning pada kemampuan komunikasi dan Self Efficacy.

\section{Daftar Pustaka}

[1] Arikunto, Suharsimi. 2010. Prosedur Penelitian Suatu Pendekatan Praktek. Jakarta: Rineka Cipta.

[2] Hamdani, dan kadarisman. 2019. Self Efficacy Dan Kemampuan Komunikasi Siswa SMP. JNPM (Jurnal Nasional Pendidikan Matematika) Volume 3, No. 1, Maret 2019 DOI: http://dx.doi.org/10.33603/jnpm.v3i1.2033.

[3] Hendriana, H., Rohaeti, E. E., \& Hidayat, W. 2017. Metaphorical Thinking Learning and Junior High School Teachers' Mathematical Questioning Ability. Journal on Mathematics Education, 8(1), 55-64.

[4] Irmayanti, I. 2019. Pengaruh Model Pembelajaran Auditory Intellectually Repetition (Air) Terhadap Kemampuan Pemecahan Masalah Matematika Dan Self Efficacy Siswa. AXIOM: Jurnal Pendidikan dan Matematika, 8(2).

[5] Maddux, J. E. 2016. Self-efficacy.In Interpersonal and Intrapersonal Expectancies (pp. 55-60). Routledge.

[6] Mukaromah. 2018. Pengaruh Model Problem Based Learning Terhadap Kemampuan Komunikasi Matematika Dan Self Confidence Siswa (Studi pada Siswa Kelas VIII SMP Negeri 2 Sendang Agung Semester Genap Tahun Pelajaran 2017/2018). Skripsi ,Universitas Lampung. 
Hal : $62-71$

[7] Yanti, Hirda. 2017. Penerapan Model Problem Based Learning (PBL) Terhadap Kemampuan Komunikasi Dan Kemampuan Pemecahan Masalah Matematika Siswa SMP LUBUK LINGGA. Jurnal Pendidikan Matematika Raflesia Vol. 2 No. 2 Tahun 2017.

[8] Yanti, Fitri. 2016. Pengaruh model problem based learning terhadap kemampuan komunikasi dan self confidence siswa kelas VII SMP N 20 Bandar Lampung. Jurnal pendidikan matematika universitas Lampung.

[9] Yanti, Indri. 2018. Pengaruh model problem based learning terhadap kemampuan komunikasi lisan dan hasil belajar kognitif siswa SMA N 15 Bandar Lampung. Jurnal pendidikan matematika universitas Lampung.

[10] Widiyanto. 2013. Pengaruh Self-Efficacy Dan Motivasi Berprestasi Siswa Terhadap Kemandirian Belajar Mata Pelajaran K3 (Keselamatan Dan Kesehatan Kerja) Di Smk N 2 Depok. Skripsi Universitas Negeri Yogyakarta. 